\title{
Mindfulness and Next-Generation Members of Family Firms: A Source for Sustainability
}

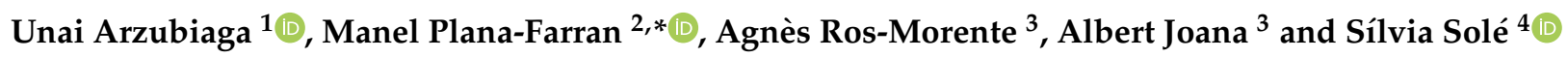 \\ 1 Department of Financial Economics I, University of the Basque Country, 48008 Bilbao, Spain; \\ unai.arzubiaga@ehu.eus \\ 2 Department of Business Administration, University of Lleida, 25001 Lleida, Spain \\ 3 Faculty of Education, Psychology and Social Work, University of Lleida, 25001 Lleida, Spain; \\ a.ros@pip.udl.cat (A.R.-M.); ajoana@activamutua.es (A.J.) \\ 4 Faculty of Nursing and Physiotherapy, University of Lleida, 25198 Lleida, Spain; silvia.sole@udl.cat \\ * Correspondence: manel.plana@udl.cat
}

Citation: Arzubiaga, U.; Plana-Farran, M.; Ros-Morente, A.; Joana, A.; Solé, S. Mindfulness and Next-Generation Members of Family Firms: A Source for Sustainability. Sustainability 2021, 13, 5380. https://doi.org/10.3390/ su13105380

Academic Editors: Felipe Hernández Perlines, Antonio Ariza-Montes and Gabriele Giorgi

Received: 30 March 2021

Accepted: 9 May 2021

Published: 11 May 2021

Publisher's Note: MDPI stays neutral with regard to jurisdictional claims in published maps and institutional affiliations.

Copyright: (c) 2021 by the authors. Licensee MDPI, Basel, Switzerland. This article is an open access article distributed under the terms and conditions of the Creative Commons Attribution (CC BY) license (https:/ / creativecommons.org/licenses/by/ $4.0 /)$.

\begin{abstract}
Family businesses are considered complex organizations where emotional and management challenges need to be faced. This is even more difficult when time of succession arrives and the new members are expected to engage with the business. In this study, a total of 204 university students were asked about their present and future situation regarding the family business. Mindfulness levels were also evaluated using the Mindful Attention Awareness Scale. There were no significant mindfulness level differences between students who pertained to a family business and those who did not. In the first group, however, those students who were sure about their future in the family business, and had more motivation about it, obtained higher scores on the mindfulness scale as well as being more satisfied with their social relationships. It could be concluded that certainty and motivation about their future in a family business of young family business members correlates with higher mindfulness levels and social well-being.
\end{abstract}

Keywords: family firm successor; mindfulness; family firms; intention to join; future expectations

\section{Introduction}

Family business succession has received increased attention in family business research in recent years [1,2], as such firms are regarded as the backbone of economic growth in both advanced and emerging economies $[3,4]$. Despite their great relevance, however, family businesses have usually low survival rates, since only $30 \%$ of them transition to the second generation, whereas only $10-15 \%$ of family businesses reach the third generation [5]. As such, the debate about the social sustainability of family businesses and the preservation of their family heritage is becoming a relevant topic in last year [6]. Regarded as a tripartite concept consisting of an economic, ecological, and social dimension according to the so-called "three pillar model" [7,8], it is afirmed that only when a family business is able to balance these three dimensions can survive in the long run. More specifically, apart from the general external challenges that all businesses have to deal with, such as increasing and global market competition, market turbulence, and emerging technological advances and disruptions [9], the reason for these low survival rates seems to lie in the fact that many of these businesses do not properly manage the organizational internal challenges that they have to face [10]. In this vein, one of the main challenges of family firms in obtaining transgenerational success is adequately preparing the next generation for running the business in the near future [11].

In family businesses, the complex interconnection between the family and the business subsystems gives special importance to both worldview and behavioral aspects [12]. However, only mindful family firms, understood as the ones conscious of their willingness to preserve their affective endowment, have a specific way of combining family and business 
desires, by obtaining a realistic outlook on their surroundings [13]. Hence, as long as mindfulness entails the ability to scan the environment and be alert to multiple perspectives that can help the organization to achieve the desirable outcome [14], developing mindfulness among new generations may contribute to a better understanding of how to manage the paradoxes that stem from the conflicting perspectives, values, and goals posed by family and business. Nevertheless, there is a lack of evidence about which factors affect the level of mindfulness of potential successors in family businesses.

In view of the above research gap, the present study attempts to address the potential effects of different personal attributes and horizons in the mindfulness level of potential successors in family businesses. Employing a data set of 204 Business Administration and Law students, the present study is designed to fill this gap by introducing the idea that mindfulness could be a powerful tool that offers relevant benefits to potential successors of family businesses. This research makes a relevant contribution to both family business and mindfulness literatures by empirically investigating how some of the main attributes of the potential successors (i.e., having or not having a family business in the family; the generation of the family to which the potential successor belongs) and their future expectations (intention of joining the family business; certainty and clarity levels about their professional future) influence these successors' mindfulness levels. In this study, levels of mindfulness among young people who form part of a family business have been found to be clearly affected by their certainty and expectations regarding their own incorporation into the business. The higher the intention and certainty of joining the family business and the more motivation to form part of it, the higher the levels of well-being and attention among the students surveyed. On the other hand, we also found that uncertainty and a lack of clarity regarding their professional future within the family business, represented by doubts over whether they are going to join it or not, affect the levels of well-being, concentration capacity, and full awareness of the potential successors of family businesses, resulting in lower levels of mindfulness. Thus, we propose that the capacity for attention and proactivity of new generations, as well as the ability to perceive their environment and adapt to change in a scenario like the current one, are fundamental characteristics for future leaders of family businesses [10]. This research also contributes to a similar discussion in the mindfulness literature. Specifically, it adds to the debate explored by [15] Pandey et al. (2017) about the influence of mindfulness on human thought and behavior, given the comprehensive influence of mindfulness on it.

The rest of the paper is structured as follows. In the second section we set the theoretical background where we develop the main concepts of the study. In the third section, we describe the sample and research methodology. In the fourth section, we provide the results. Finally, in the fifth section we discuss the main findings, contributions, and limitations of our study, and propose areas for further research.

\section{Theoretical Background and Development of Hypotheses}

\subsection{Family Businesses: The Need for Managing Complex and Paradoxical Organizations}

Family businesses are characterized by visible and active owners, long-term orientation, collective identity, family values, emotional ownership, and a desire for the firm to persist across generations $[16,17]$. These organizations have historically been regarded as complex entities where family and commercial logic need to be accommodated in a single organization [18]. In this sense, family and the business subsystems have been depicted as two conflicting social systems that represent emotional and business arenas, respectively [19]. The potential for this conflict was considered to be even higher as more generations become involved in the business because of divergent goals and attitudes across generations [20].

Nevertheless, this view has evolved toward a unified systems model of family organization that highlights the prevailing interaction among its individual members, the family, and the business [21]. As such, a correct integration of subsystems can be the source of competitive advantage for a family organization [22]. In other words, family and business 
are not necessarily competing forces, since synergies may be achieved by linking these two perspectives [23]. In this sense, family businesses may benefit from a paradoxical management [24], as the juxtaposition of familial influence with traditional business goals creates the distinctive, paradoxical landscape of the family firm [25]. That is why leaders who think paradoxically - those that are capable of embracing and synthesizing competing demands-are better positioned to maximize the positive potential of paradox [26]. Paradoxical tensions demand paradoxical thinking, a more fluid and holistic mindset that leverages the distinctions and synergies between elements in search of solutions [27]. In family firms, the ability to see both sides of paradoxical problems in family businesses is a strong driver of business adaptability and survival [28]. More specifically, paradoxical management may help taking advantage of combining the presumed logic of the family system in terms of tradition, emotional/irrational decision-making, nepotism, long-term orientation, and non-financial values with the presumed logic of the business system characterized by renewal, rational decision making, meritocracy, short-term perspective, and financial values [19].

Nevertheless, confronting paradoxical situations is not easy, since they cannot be solved but only managed [29]. This is a great challenge for decision makers given that from early childhood on we are educated to solve problems or make them disappear [30]. In this respect, it is essential for the long-term success of a family business that it is ultimately run by a competent and well-motivated successor [31]. Regarding the former, the competence of a successor has been closely joined to general factors such as educational background as well as experience within and outside the family business but also to more specific skills such as strategic, marketing, and financial skills [32]. Nevertheless, in recent years, the focus of the desirable attributes of successors has been put on more behavioral aspects such as the attitude toward entrepreneurial career, affective commitment to the family business [33], and, in particular, the capability to manage internal conflicts within the firm and the paradoxes that emerge from them [34]. Therefore, in the following subsections the importance, benefits, and potential drivers of a flourishing tool for managing the conflicts and the paradoxes arising within the family firm are discussed: mindfulness.

\subsection{Mindfulness and Family Firms}

Mindfulness practice is increasingly adopted in different work environments (e.g., hospitals, high-tech firms, investment banks, military), and it is presented as a popular and contested concept, a multi-dimensional and evaluative term, embodying multiple elements and criteria for evaluation [35]. Kabat-Zinn and associated researchers [36-39] have been responsible for an expansion of interest in mindfulness-based interventions (MBIs) in a diverse range of domains including in workplaces, businesses, schools, and hospitals, in addition to wide applications in psychology, psychotherapy, education, and medicine [40].

Mindfulness entails the ability to scan the environment and to be alert to multiple perspectives that can help the organization achieve desirable outcomes [14]. Major corporations such as Google and General Mills have already adopted mindfulness practice in their own development and training programs [41]. In the case of family businesses, mindfulness can be a great tool for managing the paradoxes that stem from the conflicting perspectives, values, and goals posed by the two family and business subsystems. Indeed, if only one side of a tension is emphasized, demand for the other will intensify, fueling anxiety and even decision-making paralysis [27]. Thus, conflicting views demand a more fluid and holistic mindset that leverages the distinctions and synergies between elements in search of solutions. The characteristics of family businesses suggest that boundaries between family and the firm are rather blurred in this kind of business [42,43].

Recent studies differentiate between individual and collective levels in mindfulness, although mindfulness has been viewed as an individual's psychological state [44] or a type of personality trait [45]. Hu et al. [46] maintain that mindfulness can be a collective-level psychological state of an organization or a team. Regarding the former, following [40], we will briefly define mindfulness based on its three most distinguishable characteristics. 
First, mindfulness consists of focusing on the present, on what is being done at this precise moment [47,48]; this means not thinking about the past or the future [49]. The second characteristic of mindfulness is that it has both an internal and external focus [47-50]. The internal factors are those related to the individual (thoughts, feelings, emotions, bodily sensations, etc.), and the external factors relate to the situation or environment (a specific physical or social event) [47]. Finally, mindfulness also consists of paying attention by means of accepting without judging, evaluating, or giving meaning to what is happening $[47,48]$. When an event is being experienced, it must be perceived in the most objective and neutral way possible, without paying attention to biased interpretations of personal memories, learned associations, prejudices, cognitive schemas, automatic thoughts, or future projections $[40,50]$.

\subsection{Main Benefits of Mindfulness in Organizations}

Different investigations and bibliographic reviews have shown how higher levels of mindfulness improve mental and physical health, and the quality of relationships with others $[47,50,51]$. In this vein, the literature highlights seven different core processes as the main ones benefiting from mindfulness in business: attention, awareness, cognition, self-regulation of behavior, emotional self-regulation, self-regulation of thought, and physiological self-regulation $[49,50]$.

First, with regard to attention, individuals can focus more effectively on what they are doing at that moment, without being distracted by internal and external factors [50]. More attentive employees are better able to achieve work-related goals by maintaining adaptive behaviors [52]. Improved attention will influence their awareness, cognition, emotional regulation, behavior, and physiology [50]. Second, improved awareness enables workers to reduce the impact of stressful situations. It is also negatively related to emotional exhaustion and positively related to job satisfaction and psychological needs [52]. Third, when paying attention to the task and not getting distracted, cognitive ability improves and consequently employees also obtain greater cognitive flexibility [50]. This makes it easier for them to adapt to new or unexpected conditions to improve their performance and be able to implement effective problem-solving techniques [53]. Fourth, individuals consciously self-regulate their behavior, and their responses are consequently more adaptive and logical with regard to their objectives [50]. If employees do not regulate their emotions effectively, they can present psychopathological problems such as anxiety, depression, schizophrenia, addiction to substance use, and eating disorders [54,55]. Thus, mindfulness contributes to individuals being less likely to suffer from this type of disorder. It also makes it easier for employees to be more empathetic to one another and decrease mental rumination, that is, the constant loop of thoughts in our head [49,50,56]. Fifth, with regard to the self-regulation of thought, mindfulness allows individuals to observe what is happening (inside and outside) from a more objective point of view, separating the event, thought, or emotions from personal attributions linked to beliefs, memories, learning, or associations. Thus, negative events become less threatening, can be separated from the individual, and consequently do not negatively affect their self-esteem or self-concept $[49,51]$.

\subsection{Drivers of Mindfulness in Potential Successors in Family Firms}

The figure of the potential successor is described as someone who could, potentially, in the future, gain managerial control of the business [57]. Career intentions in new generations follow very particular paths in companies where the leadership belongs to the parents. More specifically, new generations usually transmit the challenges and opportunities related to an entrepreneurial career [58], being their own behaviors and intentions molded by the experiences of their childhood. In this sense, ref. [30] point out that parents serve as role models for their children and indicate that family support to achieve self-efficacy and controllability feelings are key to starting an entrepreneurial career or taking the baton in the family business. Furthermore, the feeling of certainty among these 
successors that they will assume the leadership of the family company may also affect their mental self-preparation for this new challenge.

Overall, we presume that the succession intention, understood in terms of the willingness to take the baton in the family firm, will be tempting only to a particular type of individual with certain levels of perceived behaviors. In other words, we expect that succession intention in family firms is not a common element present in all next-generation offspring. Indeed, some aspects, including certainty and expectations regarding their incorporation into the business family, willingness, and motivation for it will be analyzed using mindfulness level scale on students who belong to families owning and running a business.

\section{Methodology}

\subsection{Participants and Context}

The target group was all 204 students enrolled in degrees in Business Administration as well as Business Administration and Law at the University of Lleida (UdL). Following [33], the data set is based on the responses of students who have not started professional careers yet. This fact allows us to take a prospective view as well as to avoid a survivor bias from which retrospective studies usually suffer. This course is part of a cross-cutting activity in the first semester of the Faculty of Law and Economics. It is a specific activity for a two-day introductory-level program on Business, Law and Family Business. The formal program, consisting of lectures and seminar groups, was the same for all of the participating students. Of the total of 204, 11 students had to be excluded from the study because they did not answer the questions in the questionnaire devised by [56] or failed to answer some of the questions. Thus, the final sample consisted of 193 students. Participants' ages ranged from 17 to 30 years old, with a median of 19 . The mean age was 20.1 years, with a standard deviation of 2.38 points. Table 1 shows the descriptive analysis of the variables in the sample. Participants who did not have a family business $(N=114 ; 59.4 \%)$ served as a control group.

Table 1. Descriptive analysis. Characteristics of the participants in the sample $(n=193)$.

\begin{tabular}{ccccc}
\hline \multirow{2}{*}{ Variable } & \multirow{N}{*}{ Measure } & \multicolumn{2}{c}{ Descriptive } \\
\cline { 3 - 5 } & & & $\%(n)$ & Mean (S.D.) \\
\hline Gender & 190 & Men & $56.8 \%$ & $(108)$ \\
& & Women & $43.2 \%$ & $(82)$ \\
Age & 193 & Years & $20.07 \%$ & $(2.38)$ \\
Degree & 185 & Bus. Admin & $82.7 \%$ & $(153)$ \\
& & Law & $0.5 \%$ & $(1)$ \\
& & Bus. Admin & $14.6 \%$ & $(27)$ \\
& & Law & $2.2 \%$ & $(4)$ \\
& & Other & & \\
\hline
\end{tabular}

\subsection{Procedure}

Aiming at reaching as many students as possible, they were provided with the survey at five different lecture hours. In order to avoid any potential misunderstandings or mistakes, we offered them a previous 10 min explanation of the survey. In each group, the students were given $15 \mathrm{~min}$ at the end of the first lecture session in addition to a $10 \mathrm{~min}$ break to respond to the survey. Participation was anonymous and not mandatory. The entire data collection was completed one month before the final exam.

\subsection{Instruments and Measures}

In the present investigation, a questionnaire with different sections was used. On the one hand, a section about demographic variables was utilized in order to ask the students about their gender, age, and the university degree they were taking. On the other hand, a section on the student's situation with regard to family businesses was used, in which the 
students were asked whether their family had a family business and, if so, which generation of the family he/she belonged to. Furthermore, the students were also asked whether they wanted to join the family business, whether they would work in it, whether they saw themselves as a future manager in it, etc. The questionnaire also contained questions related to social relationships. The questions related to expectations, behavior, and perspectives were composed of 12 Likert-type response questions, with answers ranging from 1 to 3.

The results of this test were compared with the mindfulness score obtained by each student in the Mindful Attention Awareness Scale (MAAS), in its spanish version [59]. This scale has 15 Likert-type response items (Figure 1) ranging from 1 (almost always) to 6 (almost never) and is designed to provide an overall assessment of an individual's dispositional capacity to be attentive and aware of experiencing the present moment in everyday life. Therefore, higher scores on the MAAS scale will imply a greater capacity to be present in the "here and now". This instrument takes mindfulness to be an unifactorial construct, encompassing awareness and present attention as the only factor. It has good convergent validity with the Five Facets Mindfulness Questionnaire (FFMQ) [60] and discriminatory validity with respect to depressive symptoms. It also has good reliability indexes (Cronbach's $\alpha=0.89$ ), good temporal stability (studying reliability, it obtains a Pearson's correlation of 0.823 with a $p<0.001$ ), and replicates the original univariate structure that accounts for $42.8 \%$ of the total variance.

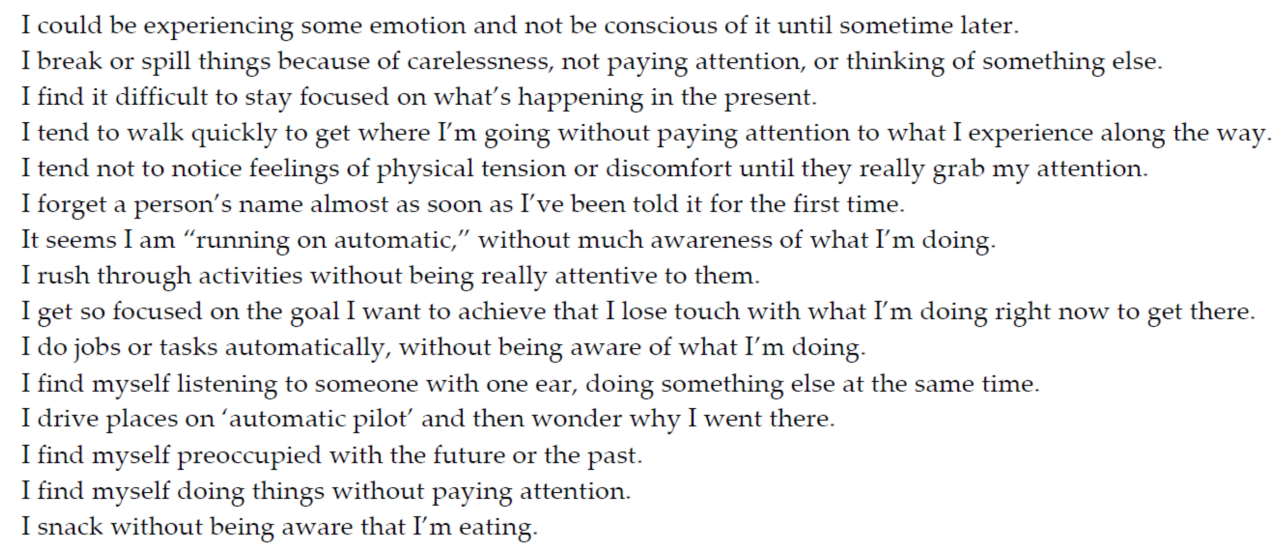

Figure 1. Mindful Attention Awareness Scale (MAAS) items.

\subsection{Statistical Analysis}

The obtained data were analyzed using Statistical Product and Service Solutions (SPSS) version 22 (IMB Corporation, 2013, IBM SPSS Statistics v 25.0 for Windows; Armonk, NY, USA). The distribution of frequencies and percentages was used with the qualitative (nominal) variables, with an estimate of $95 \%$ confidence intervals. For quantitative variables, the data were explored using the Q-Q plot for normality fit, histogram, coefficients of skewness, and kurtosis/height, together with the Kolmogorov-Smirnov goodness-of-fit test and description with the usual tools of centrality (mean, median) and variability (standard deviation and range). Regarding the reliability of our measurement scale, this was estimated with Cronbach's $\alpha$ coefficient and intraclass correlation.

In order to show significant differences between two means of independent groups, the Student's $t$-test was used; when comparing gender with level of mindfulness, for example. When trying to contrast more than two means, analysis of variance (ANOVA) of a fixed effects factor was used. In some cases, the multiple contrast test (Tukey) was applied between pairs of groups in order to observe their significance. In addition, the effect size was estimated using $\mathrm{R}^{2}$ and the Chi-square test, for the crossover of categorical variables ( $\mathrm{R}^{2}$ estimated from Cramér's V). Finally, the usual 5\% level of significance was established (significant if $p<0.05$ ), except in the KS goodness of fit test, where only serious deviations were considered significant, that is, at $1 \%(p<0.01)$. 


\section{Results}

\subsection{Exploratory and Descriptive Analysis}

4.1.1. Description of the Sample

As Table 1 shows, a similar number of men $(n=108)$ and women $(n=82)$ participated in the present study; three people did not answer this question. The mean age was 20.7 years (2.38 S.D.). With regard to their education, a large part of the sample (82.7\%) was studying Business Administration, while the second most studied degree was the double degree in Business Administration and Law (14.6\%).

\subsubsection{Mindfulness Level}

First, a general descriptive analysis of the participants' responses to the items on the MAAS scale was performed on a scale of 1-6, in accordance with their quantitative Likert nature, from almost always to almost never. The results of this description are summarized in Table 2: although some subjects did not respond to any of the items (missing values), the maximum loss was not significant ( 3 cases in Item 1, or 1.6\%, for example). For this reason, the following tables do not have the same number of subjects, the figure varying from 189 to 192.

Table 2. Descriptive analysis. Variables for the Mindful Attention Awareness Scale (MAAS) items $(N=192)$.

\begin{tabular}{cccccc}
\hline \multirow{2}{*}{ Variable } & \multicolumn{3}{c}{ Centrality } & \multicolumn{2}{c}{ Variability } \\
\cline { 2 - 6 } & $\boldsymbol{N}$ & Mean & Median & Range (Min./Max.) & S.D. \\
\hline MAAS 1 & 189 & 4.23 & 4.00 & $1 / 6$ & 1.02 \\
MAAS 2 & 191 & 4.58 & 5.00 & $1 / 6$ & 1.24 \\
MAAS 3 & 192 & 4.23 & 4.00 & $1 / 6$ & 1.14 \\
MAAS 4 & 191 & 3.36 & 3.00 & $1 / 6$ & 1.29 \\
MAAS 5 & 190 & 4.23 & 4.00 & $1 / 6$ & 1.20 \\
MAAS 6 & 191 & 4.31 & 5.00 & $1 / 6$ & 1.47 \\
MAAS 7 & 191 & 4.30 & 4.00 & $2 / 6$ & 1.07 \\
MAAS 8 & 192 & 4.06 & 4.00 & $1 / 6$ & 1.13 \\
MAAS 9 & 191 & 4.21 & 4.00 & $1 / 6$ & 1.08 \\
MAAS 10 & 190 & 2.12 & 4.00 & $1 / 6$ & 1.16 \\
MAAS 11 & 191 & 3.99 & 4.00 & $1 / 6$ & 1.24 \\
MAAS 12 & 190 & 4.93 & 5.00 & $2 / 6$ & 1.23 \\
MAAS 13 & 191 & 4.04 & 4.00 & $1 / 6$ & 1.11 \\
MAAS 14 & 192 & 4.28 & 4.00 & $1 / 6$ & 1.41 \\
MAAS 15 & 192 & 4.55 & 5.00 & $1 / 6$ &
\end{tabular}

All of the items presented median values of 4 or 5 points, and mean values of between 3.36 (Item 4 ) and 4.93 (Item 12); that is, there was a slight tendency toward the central values on the scale. Practically all of the items cover the full range of the response scale (1-6), with a reasonable degree of variability (standard deviations of between 1 and 1.5 points), which implies the presence of responses toward always and never, but without extreme values being frequent. The reliability of the responses given by these participants to the 15 items was estimated using Cronbach's $\alpha$ coefficient of internal consistency and corroborated by means of intraclass correlation. The result obtained by both methods (0.837) led us to conclude that the degree of reliability achieved by the instrument was high and, therefore, acceptable.

From the responses provided by the participants to these items, a summary variable was created that assesses each subject's overall level of mindfulness through the median value of these responses. Thus, the resulting value assesses each subject on the same item response scale $(1=$ almost always; $6=$ almost never $)$. This variable took values in the range $2.00-6.00$, with a median of 4.00 and a mean value of 4.32 points. These results indicate a good mindfulness level in general. But if we analyze the items with more detail, we can 
observe that items 4 and 10 are those with lower means. So it seems that students are less mindful when they are doing tasks or jobs and walking quickly, activities they do without paying attention. On the other hand, best results are found in items 2 and 15, when asking about if they break or spill things because of carelessness and eating without being totally aware of it."

\subsection{Inferential Intergroup Analysis}

Student's $t$-test was used to contrast the possible existence of significant differences between men and women. This method was supplemented by estimating the effect size; rather than using Cohen's $d$ to compare mean values, the value of the $R^{2}$ coefficient was employed due to its greater ease of interpretation and greater generality. The results are shown in Table 3. The mean values were found to be practically the same for both genders (4.32), so the difference between them (0.0015) could not in any way reach statistical significance (in this case, $p>0.05$ ).

Table 3. Mindfulness by gender $(n=189)$.

\begin{tabular}{cccccccc}
\hline & \multicolumn{2}{c}{ Men } & \multicolumn{2}{c}{ Women } & \multicolumn{2}{c}{$T$-Student } & \multirow{2}{*}{$\mathbf{R}^{2}$} \\
\cline { 2 - 6 } & $N$ & Mean (S.D.) & $N$ & Mean (S.D.) & Value & $p$ & \\
\hline $\begin{array}{c}\text { Mean level of } \\
\text { mindfulness }\end{array}$ & 108 & $4.319(0.87)$ & 81 & $4.321(0.80)$ & -0.01 & $0.990{ }^{* n . s}$ & 0.000 \\
\hline${ }^{*} p<0.05$ sig. n.s.: no significant. & & & & &
\end{tabular}

According to the responses obtained from participants, $40.6 \%$ (78 of 192) had a family business. Using the statistical procedure outlined above, it was determined whether this factor significantly influences the level of mindfulness. The results (Table 4) presented a very slightly lower mean value (0.0752) in those cases that did have a family business.

Table 4. Mindfulness by having a family business (F.B.) $(n=192)$.

\begin{tabular}{|c|c|c|c|c|c|c|c|}
\hline & \multicolumn{2}{|r|}{ Has F.B. } & \multicolumn{2}{|c|}{ Does Not Have F.B. } & \multicolumn{2}{|c|}{ T-Student } & \multirow{2}{*}{$\mathbf{R}^{2}$} \\
\hline & $N$ & Mean (S.D.) & $N$ & Mean (S.D.) & Value & $p$ & \\
\hline $\begin{array}{l}\text { Mean level of } \\
\text { mindfulness }\end{array}$ & 78 & $4.28(0.87)$ & 114 & $4.35(0.81)$ & -0.61 & $0.541^{* n \cdot s}$ & 0.002 \\
\hline
\end{tabular}

Participants who did have a family business $(n=78)$ were filtered in order to test for the possible existence of differences between genders a second time. However, no significant differences were observed.

Continuing with the analysis of this sample subgroup, the possible effect of the generational factor on the level of mindfulness was contrasted. When we speak of first generation, we mean that the students' predecessors created the company, that is, the students are the potential second generation. In this case, ANOVA with one fixed effect factor was used (Table 5). The average value was observed to be higher in cases where the family business was second generation (4.46) compared to a third or later generation (4.28) and especially a first-generation family business (4.19). However, the differences did not reach statistical significance (in this case, $p>0.05)$, nor can the effect size $(1.8 \%)$ be considered to support the existence of a relationship.

This subgroup of the sample was then compared according to their intention/desire to join their family business. In this case (Table 6), ANOVA did detect statistically significant differences $(p<0.05)$, with a moderately high effect size $(9.3 \%)$. The data indicated that the highest mean was found for those participants who stated that they were going to work in their family's business (4.60), followed closely by those who were not (4.34), and far from those who had doubts or responded that they did not know (3.98). When Tukey's post-hoc 
test, or a-posteriori contrast test, was applied to the paired groups, the only significant contrast $(p<0.05)$ was observed between the two extreme groups (yes/do not know), a difference between the two being estimated at between 0.186 and 1.037 points (95\% CI).

Table 5. Mindfulness by generation of F.B. $(n=75)$.

\begin{tabular}{lccccccccc}
\hline & \multicolumn{2}{c}{ 1st Generation } & \multicolumn{2}{c}{ 2nd Generation } & \multicolumn{2}{c}{ 3rd Generation } & \multicolumn{2}{c}{ ANOVA } & \multirow{2}{*}{$\mathbf{R}^{\mathbf{2}}$} \\
\cline { 2 - 8 } & $N$ & Mean (S.D.) & $N$ & Mean (S.D.) & $N$ & Mean (S.D.) & Value & Sig. & \\
\hline $\begin{array}{c}\text { Mean level of } \\
\text { mindfulness }\end{array}$ & 34 & $4.19(0.92)$ & 25 & $4.46(0.76)$ & 16 & $4.28(0.97)$ & 0.67 & $0.513^{* n . s}$ & 0.018 \\
\hline$p<0.05$ sig. n.s: no significant. & & & & & &
\end{tabular}

Table 6. Mindfulness by intention to join the F.B. $(n=77)$.

\begin{tabular}{|c|c|c|c|c|c|c|c|c|c|}
\hline & \multicolumn{2}{|r|}{ Wants To } & \multicolumn{2}{|c|}{ Does Not Want To } & \multicolumn{2}{|c|}{ Does Not Know } & \multicolumn{2}{|c|}{ ANOVA } & \multirow{2}{*}{$\mathbf{R}^{2}$} \\
\hline & $N$ & Mean (S.D.) & $N$ & Mean (S.D.) & $N$ & Mean (S.D.) & Value & Sig. & \\
\hline $\begin{array}{l}\text { Mean level of } \\
\text { mindfulness }\end{array}$ & 26 & $4.60(0.69)$ & 19 & $4.34(0.97)$ & 32 & $3.98(0.88)$ & 3.80 & $0.027 *$ & 0.093 \\
\hline
\end{tabular}

Regarding the comparison based on the belief that they would end up working in the family business (Table 7), a quasi-significant relationship was found $(p<0.10)$ accompanied by a moderate effect $(6.9 \%)$. Therefore, despite a lack of solid evidence, there are clear indications of a possible relationship between this factor and mindfulness. According to the data we have, it would seem that the significance of the differences is the same as with the previous contrast, that is, those who believed that they would work in the family business, were the ones with the highest mean value (4.58), while those who had doubts about it, were the ones with the lowest mean value (4.06). In fact, if the other group is omitted and only these two groups are compared using Student's $t$-test, the significance of this difference can be proven $(t$-value $=2.48 ; p=0.016$; effect size: $9.4 \%)$.

Table 7. Mindfulness by belief they will work in the F.B. $(n=77)$.

\begin{tabular}{|c|c|c|c|c|c|c|c|c|c|}
\hline & \multicolumn{2}{|c|}{ Believe They Will } & \multicolumn{2}{|c|}{ Believe They Will Not } & \multicolumn{2}{|c|}{ Do Not Know } & \multicolumn{2}{|c|}{ ANOVA } & \multirow{2}{*}{$\mathbf{R}^{2}$} \\
\hline & $N$ & Mean (S.D.) & $N$ & Mean (S.D.) & $N$ & Mean (S.D.) & Value & Sig. & \\
\hline $\begin{array}{l}\text { Mean level of } \\
\text { mindfulness }\end{array}$ & 26 & $4.58(0.77)$ & 16 & $4.28(1.03)$ & 35 & $4.06(0.83)$ & 2.72 & $0.027^{*}$ n.s & 0.069 \\
\hline
\end{tabular}

\section{Discussion and Remarks}

This study sheds light on the relevant and non-studied effects of different personal attributes and horizons in the mindfulness level of potential successors in family businesses. Based on the increasing mindfulness literature $[14,40,41]$, this study introduces the idea that mindfulness could be a powerful tool that offers relevant benefits to potential successors of family businesses. More specifically, this research uses the MAAS mindfulness scale to determine the level of well-being and attention capacity among university students who belong to a business-owning family based on their own perceptions and conviction regarding their possible incorporation into the family business and whether this is going to happen at some time in the future. Relatedly, this research also analyzes whether or not being a member of a business family has any impact on well-being and whether there are differences between these and other students who do not belong to a family business. The results show that there are no apparent significant differences in the level of mindfulness among students who belong to a family business, and there do not appear to be any differences in gender.

However, this study has discovered some relevant findings that may add to the literature on both family business and mindfulness. More specifically, this study has found that young people's certainty and expectations regarding their incorporation into the family 
business have a clear impact on their levels of mindfulness. The degree of certainty was based on students' affirmative or negative response to the question of whether they will join and their motivation to face the challenge of being part of the family business, those who answered yes having a higher level of mindfulness and obtaining a statistically significant difference compared to those who answered that they did not know. We can therefore state that uncertainty and a lack of clarity have a direct impact on levels of emotional well-being and mindfulness, represented by mindfulness in young people who belong to a family business. In this sense, the more intention and self-belief to join the family business and the more motivation to form part of it, the higher the levels of well-being and attention among the students surveyed, as represented by levels of mindfulness. This finding complements the ones shown by [61] as well as by [11] about the relevance of junior generation's attitudes, intention, and commitment toward succession.

On the other hand, uncertainty and a lack of clarity regarding their professional future within the family business, represented by doubt around whether they are going to join the business or not, affects levels of well-being, concentration capacity, and full awareness among potential successors of family businesses, who display lower levels of mindfulness. In this sense [62], in line with [63] highlight that succession processes are often surrounded by contextual instability as a consequence of their unclear financial results as well as the difficulties in foreseen their non-economic outcomes. The latter seems to be related to the quality of the social relationships of potential successors. In our study, students with higher levels of mindfulness who belong to a business family have been observed to be more satisfied with their social relationships, and more certain about wanting to join and end up working in the family business. We can therefore state that these individuals are motivated and determined to work in the family business.

These results are complemented by previous research on the effects of mindfulness levels in companies, which found that the higher the mindfulness levels of the members, the greater their contribution to the development and growth of the company $[40,47-50,52,64]$. This is very closely related to some of our findings. In this sense, those students who scored highest in terms of mindfulness level belonged to a business family, were convinced that they were going to join the family business, and were motivated to do so. These factors provide the basis for a positive contribution to the development and growth of the family business.

Our insights into the importance of the intention to join the family business as well as the expectations of potential successors in their mindfulness levels offer relevant and insightful managerial implications. Increasing mindfulness levels in successors is a complex challenge for family businesses, and our study finds that this is more effective if the potential successors have already decided that they will join their family business and have high expectations for the firm's future. Rather than simply pushing the potential successors to acquire specific management knowledge at the highest education levels, our study encourages family SME (Small \& Medium Enterprises) owners to instill certainty in the next generation about their future role in the business as well as positive expectations about the firm's future. This idea goes is in line with the findings shown by [65], who highlighted the importance of taking care of the incentives of new successors when designing the succession processes.

This study has some limitations that offer opportunities for future research. This study focuses not only on one country, Spain, but also on one university in a specific region, Lleida. Therefore, any conclusions should be interpreted carefully in other regions or in other collectives of potential successors. As such, these results call for different settings to theorize about mindfulness in family firms, and future research should take advantage of integrating findings across different contexts and build more cumulative research results. Analysis of mindfulness level in a work setting is strong, but not between members who belong to a family business or potential successors in a family business. Mindfulness practices are supported by considerable research in domains other than the workplace (e.g., [66]); however, more research is needed to enrich the family business 
literature from a mindfulness and psychological perspective. For example, future research is needed to assess whether and to what extent our findings apply to family firms where the succession process is at different stages. Indeed, our findings, although explorative, indicate the opportunity for future research to explore further the heterogeneous drivers of the level of mindfulness that the successors in family firms may have. On the other hand, this is a cross-sectional study that assessed potential successors' perceptions at one point in time. The level of mindfulness and its potential drivers are dynamic variables that should be analyzed over time. Therefore, future studies should seek to capture those constructs longitudinally.

Author Contributions: All of the authors contributed to conceptualization, formal analysis, investigation, methodology and writing and editing the original draft. All authors have read and agreed to the published version of the manuscript.

Funding: This research received no external funding.

Institutional Review Board Statement: Informed consent was obtained from the respondents of the survey. Informed Consent Statement: Not applicable.

Data Availability Statement: The data will be made available on request from the corresponding author.

Conflicts of Interest: The authors declare no conflict of interest.

\section{References}

1. Van Helvert-Beugels, J.; Nordqvist, M.; Flören, R. Managing tensions as paradox in CEO succession: The case of nonfamily CEO in a family firm. Int. Small Bus. J. 2020, 38, 211-242. [CrossRef]

2. Martin-Cruz, N.; Barros Contreras, I.; Hernangómez Barahona, J.; Pérez Fernández, H. Parents' Learning Mechanisms for Family Firm Succession: An Empirical Analysis in Spain through the Lens of the Dynamic Capabilities Approach. Sustainability 2020, 12, 8220. [CrossRef]

3. Holt, D.T.; Pearson, A.W.; Payne, G.T.; Sharma, P. Family business research as a boundary-spanning platform. Fam. Bus. Rev. 2018, 31, 14-31. [CrossRef]

4. Oudah, M.; Jabeen, F.; Dixon, C. Determinants linked to family business sustainability in the UAE: An AHP approach. Sustainability 2018, 10, 246. [CrossRef]

5. Hiebl, M.R. Family involvement and organizational ambidexterity in later-generation family businesses: A framework for further investigation. Manag. Decis. 2015, 53, 1061-1082. [CrossRef]

6. Hernández-Perlines, F.; Rung-Hoch, N. Sustainable Entrepreneurial Orientation in Family Firms. Sustainability 2017, 9 , 1212. [CrossRef]

7. Kleine, A.; von Hauff, M. Sustainability-Driven Implementation of Corporate Social Responsibility: Application of the Integrative Sustainability Triangle. J. Bus. Ethics 2009, 85, 517. [CrossRef]

8. Suess-Reyes, J.; Fuetsch, E. The future of family farming: A literature review on innovative, sustainable and succession-oriented strategies. J. Rural. Stud. 2016, 47, 117-140. [CrossRef]

9. Arzubiaga, U.; Maseda, A.; Iturralde, T. Exploratory and exploitative innovation in family businesses: The moderating role of the family firm image and family involvement in top management. Rev. Manag. Sci. 2019, 13, 1-31. [CrossRef]

10. Steier, L.P.; Chrisman, J.J.; Chua, J.H. Governance challenges in family businesses and business families. Entrep. Theory Pract. 2015, 39, 1265-1280. [CrossRef]

11. Magrelli, V.; Rondi, E.; de Massis, A.; Kotlar, J. Generational brokerage: An intersubjective perspective on managing temporal orientations in family firm succession. Strateg. Organ. 2020, 1476127020976972. [CrossRef]

12. Burch, G.F.; Batchelor, J.H.; Burch, J.J.; Heller, N.A. Rethinking family business education. J. Fam. Bus. Manag. 2015, 5, 277-293. [CrossRef]

13. Dayan, M.; Ng, P.Y.; Ndubisi, N.O. Mindfulness, socioemotional wealth, and environmental strategy of family businesses. Bus. Strategy Environ. 2019, 28, 466-481. [CrossRef]

14. Qiu, J.X.; Rooney, D. Addressing unintended ethical challenges of workplace mindfulness: A four-stage mindfulness development model. J. Bus. Ethics 2019, 157, 715-730. [CrossRef]

15. Pandey, A.; Chandwani, R.; Navare, A. How can mindfulness enhance moral reasoning? An examination using business school students. Bus. Ethic- A Eur. Rev. 2018, 27, 56-71. [CrossRef]

16. Berrone, P.; Cruz, C.; Gomez-Mejia, L.R. Socioemotional wealth in family firms: Theoretical dimensions, assessment approaches, and agenda for future research. Fam. Bus. Rev. 2012, 25, 258-279. [CrossRef]

17. Miller, D.; Le Breton-Miller, I. Managing for the Long Run: Lessons in Competitive Advantage from Great Family Businesses; Harvard Business Press: Boston, MA, USA, 2005. 
18. Jaskiewicz, P.; Heinrichs, K.; Rau, S.B.; Reay, T. To be or not to be: How family firms manage family and commercial logics in succession. Entrep. Theory Pract. 2016, 40, 781-813. [CrossRef]

19. Zellweger, T. Managing the Family Business: Theory and Practice; Edward Elgar Publishing: Cheltenham, UK, 2017.

20. Pieper, T.M.; Smith, A.D.; Kudlats, J.; Astrachan, J.H. Article Commentary: The Persistence of Multifamily Firms: Founder Imprinting, Simple Rules, and Monitoring Processes. Entrep. Theory Pract. 2015, 39, 1313-1337. [CrossRef]

21. Chirico, F.; Melin, L.; Salvato, C.; Seidl, D.; Hitt, M. Call for Papers Special Issue on Advancing Organization Studies in Family Business Research: Exploring the multilevel complexity of family organizations. Organ. Stud. 2015, 36, 1269-1272.

22. Habbershon, T.G.; Williams, M.; MacMillan, I.C. A unified systems perspective of family firm performance. J. Bus. Ventur. 2003, 18, 451-465. [CrossRef]

23. Nordqvist, M.; Melin, L. Entrepreneurial families and family firms. Entrep. Reg. Dev. 2010, 22, 211-239. [CrossRef]

24. Zellweger, T.M.; Nason, R.S.; Nordqvist, M.; Brush, C.G. Why do family firms strive for nonfinancial goals? An organizational identity perspective. Entrep. Theory Pract. 2013, 37, 229-248. [CrossRef]

25. Irava, W.J.; Moores, K. Clarifying the strategic advantage of familiness: Unbundling its dimensions and highlighting its paradoxes. J. Fam. Bus. Strategy 2010, 1, 131-144. [CrossRef]

26. Smith, W.K.; Lewis, M.W. Toward a theory of paradox: A dynamic equilibrium model of organizing. Acad. Manag. Rev. 2011, 36, 381-403.

27. Ingram, A.E.; Lewis, M.W.; Barton, S.; Gartner, W.B. Paradoxes and innovation in family firms: The role of paradoxical thinking. Entrep. Theory Pract. 2016, 40, 161-176. [CrossRef]

28. Schuman, A.; Stutz, S.; Ward, J. Family Business as Paradox; Springer: Berlin/Heidelberg, Germany, 2010.

29. Zhang, Y.; Waldman, D.A.; Han, Y.L.; Li, X.B. Paradoxical leader behaviors in people management: Antecedents and consequences. Acad. Manag. J. 2015, 58, 538-566. [CrossRef]

30. Audebrand, L.K.; Camus, A.; Michaud, V. A mosquito in the classroom: Using the cooperative business model to foster paradoxical thinking in management education. J. Manag. Educ. 2017, 41, 216-248. [CrossRef]

31. Kandade, K.; Samara, G.; Parada, M.J.; Dawson, A. From family successors to successful business leaders: A qualitative study of how high-quality relationships develop in family businesses. J. Fam. Bus. Strategy 2020, 100334. [CrossRef]

32. Sharma, P.; Srinivas Rao, A. Successor attributes in Indian and Canadian family firms: A comparative study. Fam. Bus. Rev. 2000, 13, 313-330. [CrossRef]

33. Zellweger, T.M.; Sieger, P.; Halter, F. Should I stay or should I go? Career choice intentions of students with family business background. J. Bus. Ventur. 2011, 26, 521-536. [CrossRef]

34. Cater, I.J.J.; Kidwell, R.E.; Camp, K.M. Successor Team Dynamics in Family Firms. Fam. Bus. Rev. 2016, 29, 301-326. [CrossRef]

35. Badham, R.; King, E. Mindfulness at work: A critical re-view. Organization 2019. [CrossRef]

36. Kabat-Zinn, J. Coming to Our Senses: Healing Ourselves and the World through Mindfulness; Hyperion: New York, NY, USA, 2005.

37. Segal, Z.V.; Williams, J.M.G.; Teasdale, J.D. Mindfulness-Bases Cognitive Therapy for Depression: A New Approach to Preventing Relapse; Guilford Press: New York, NY, USA, 2002.

38. Williams, J.M.G.; Teasdale, J.D.; Segal, Z.V.; Kabat-Zinn, J. The Mindful Way through Depression: Freeing Yourself from Chronic Unhappiness; Guilford Press: New York, NY, USA, 2007.

39. Williams, J.M.G.; Kabat-Zinn, J. Mindfulness: Diverse Perspectives on Its Meaning. Origin and Applications; Routledge: London, UK, 2013.

40. Hyland, P.K.; Lee, R.A.; Mills, M.J. Mindfulness at Work: A New Approach to Improving Individual and Organizational Performance. Ind. Org. Psycho. 2015, 8, 576-602. [CrossRef]

41. Sutcliffe, K.M.; Vogus, T.J.; Dane, E. Mindfulness in Organizations: A Cross-Level Review. Annu. Rev. Organ. Psychol. Organ. Behav. 2016, 3, 55-81. [CrossRef]

42. Danes, S.M.; Morgan, E.A. Family Business-Owning Couples: An EFT View into Their Unique Conflict Culture. Contemp. Fam. Ther. 2004, 26, 241-260. [CrossRef]

43. Labaki, R.; Michael-Tsabari, N.; Zachary, R.K.; Smyrnios, K.; Poutziouris, P.; Goel, S. Emotional dimensions within the family business: Towards a conceptualization. In Handbook of Research on Family Business, 2nd ed.; Edward Elgar Publishing: Cheltenham, UK, 2013. [CrossRef]

44. Brown, K.W.; Goodman, R.J.; Inzlicht, M. Dispositional mindfulness and the attenuation of neural responses to emotional stimuli. Soc. Cogn. Affect. Neurosci. 2012, 8, 93-99. [CrossRef]

45. Bishop, S.R.; Lau, M.; Shapiro, S.; Carlson, L.; Anderson, N.D.; Carmody, J.; Segal, Z.V.; Abbey, S.; Speca, M.; Velting, D.; et al. Mindfulness: A proposed operational definition. Clin. Psychol. Sci. Pract. 2004, 11, 230-241. [CrossRef]

46. Hu, Y.; Zhao, X.; Chen, Y. The Influence of Managerial Mindfulness on Innovation: Evidence from China. Sustainability 2019, 11, 2914. [CrossRef]

47. Brown, K.W.; Ryan, R.M.; Creswell, J.D. Mindfulness: Theoretical Foundations and Evidence for its Salutary Effects. Psychol. Inq. 2007, 18, 211-237. [CrossRef]

48. Glomb, T.M.; Duffy, M.K.; Bono, J.E.; Yang, T. Mindfulness at work. In Research in Personnel and Human Resources Management; Emerald Group Publishing Limited: Bingley, UK, 2011; Volume 30, pp. 115-157. [CrossRef]

49. Brown, K.W.; Ryan, R.M. The benefits of being present: Mindfulness and its role in psychological well-being. J. Pers. Soc. Psychol. 2003, 84, 822-848. [CrossRef] 
50. Good, D.J.; Lyddy, C.J.; Glomb, T.M.; Bono, J.E.; Brown, K.W.; Duffy, M.K.; Baer, R.A.; Brewer, J.A.; Lazar, S.W. Contemplating Mindfulness at Work. J. Manag. 2016, 42, 114-142. [CrossRef]

51. Martínez-Rubio, D.; Sanabria-Mazo, J.P.; Feliu-Soler, A.; Colomer-Carbonell, A.; Martínez-Brotóns, C.; Solé, S.; Escamilla, C.; Giménez-Fita, E.; Moreno, Y.; Pérez-Aranda, A.; et al. Testing the Intermediary Role of Perceived Stress in the Relationship between Mindfulness and Burnout Subtypes in a Large Sample of Spanish University Students. Int. J. Environ. Res. Public Health 2020, 17, 7013. [CrossRef]

52. Reb, J.; Narayanan, J.; Ho, Z.W. Mindfulness at work: Antecedents and consequences of employee awareness and absentmindedness. Mindfulness 2015, 6, 111-122. [CrossRef]

53. Cañas, J.J.; Quesada, J.F.; Antoli, A.; Fajardo, I. Cognitive flexibility and adaptability to environmental changes in dynamic complex problem-solving tasks. Ergonomics 2003, 46, 482-501. [CrossRef] [PubMed]

54. Aldao, A.; Nolen-Hoeksema, S.; Schweizer, S. Emotion regulation strategies across psychopathology: A meta-analytic review. Clin. Psych. Rev. 2010, 30, 217-237. [CrossRef]

55. Kring, A.M.; Sloan, D.S. Emotion regulation and psychopathology. In Emotion Regulation and Psychopathology: A Conceptual Framework; En, A.M., Kringy, D.S.S., Eds.; Guilford Press: New York, NY, USA, 2010; pp. 13-37.

56. Gross, J.J. Handbook of Emotion Regulation, 2nd ed.; Guilford Press: New York, NY, USA, 2014.

57. Chiswell, H.M. The Importance of Next Generation Farmers: A Conceptual Framework to Bring the Potential Successor into Focus. Geogr. Compass 2014, 8, 300-312. [CrossRef]

58. Chua, J.H.; Chrisman, J.J.; Sharma, P. Defining the Family Business by Behavior. Entrep. Theory Pract. 1999, 23, 19-39. [CrossRef]

59. Soler, J.; Tejedor, R.; Feliu, A.; Pascual, J.; Cebolla, A.; Soriano, J.; Pérez, V. Propiedades psicométricas de la versión española de la escala Mindful Attention Awareness Scale (MAAS). Actas Esp. Psiquiat. 2012, 40, $19-25$.

60. Baer, R.A.; Smith, G.T.; Lykins, E.; Button, D.; Krietemeyer, J.; Sauer, S.; Walsh, E.; Duggan, D.; Williams, J.M.G. Construct Validity of the Five Facet Mindfulness Questionnaire in Meditating and Nonmeditating Samples. Assessment 2008, 15, 329-342. [CrossRef]

61. Sharma, P.; Irving, P.G. Four Bases of Family Business Successor Commitment: Antecedents and Consequences. Entrep. Theory Pract. 2005, 29, 13-33. [CrossRef]

62. Calabrò, A.; Minichilli, A.; Amore, M.D.; Brogi, M. The courage to choose! Primogeniture and leadership succession in family firms. Strat. Manag. J. 2018, 39, 2014-2035. [CrossRef]

63. Gómez-Mejía, L.R.; Haynes, K.T.; Núñez-Nickel, M.; Jacobson, K.J.L.; Moyano-Fuentes, J. Socioemotional Wealth and Business Risks in Family-controlled Firms: Evidence from Spanish Olive Oil Mills. Adm. Sci. Q. 2007, 52, 106-137. [CrossRef]

64. Levinthal, D.; Rerup, C. Crossing an Apparent Chasm: Bridging Mindful and Less-Mindful Perspectives on Organizational Learning. Organ. Sci. 2006, 17, 502-513. [CrossRef]

65. Mobbs, S.; Raheja, C.G. Internal managerial promotions: Insider incentives and CEO succession. J. Corp. Finance 2012, 18, 1337-1353. [CrossRef]

66. Chiesa, A.; Calati, R.; Serretti, A. Does mindfulness training improve cognitive abilities? A systematic review of neuropsychological findings. Clin. Psychol. Rev. 2011, 31, 449-464. [CrossRef] [PubMed] 